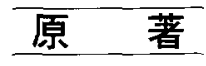

\author{
異なる生活環境による行動特性の変化 \\ 一メ =エール病と行動特性一 \\ 大貫 純一・高橋 正紘・小田桐恭子 \\ 和田 涼子・飯田 政弘
}

\title{
Behavioral Characteristics of Another Lifestyle
}

Junichi Onuki, Masahiro Takahashi, Kyoko Odagiri, Ryoko Wada, Masahiro Iida

Department of Otolaryngology, Tokai University School of Medicine

In previous study reports, we conducted a questionnaire-based study of patients with Meniere's disease and workers in the industrial company and found several behavioral characteristics specific to the patient group. To confirm our findings, we used the questionnaire in control groups from two other areas, that is, individuals from a farming district $(\mathrm{n}=161)$ and individuals from an office workers' district $(\mathrm{n}=663)$, and we compared the results from those with Meniere's disease to the results from the three control groups. As a group, patients showed a significantly strong propensity to immerse themselves in whatever they do, to be perfectionists, to worry before doing something, and to strive to meet superiors' expectations $(p<0.005)$. Between the three control groups, we did not find any significant difference in behavioral characteristics. It seems likely that patients with Meniere's disease possess specific behavioral characteristics that are not influenced by daily environmental factors. We think that stress-related behavioral characteristics may be an important underlying cause of Meniere's disease.

Key words: Meniere's disease, lifestyle, behavioral characteristics, questionnaire

\section{はじめに}

我々はライフスタイルに関するアンケート調查 を行い,メニエール病患者に特異な行動特性が多 くみられることを示唆してきだ2)。しかし，対 象として扱った一企業の勤学者集団が一般集団を 代表するかという指摘があった。メニエール病患 者には専業主婦や高齢者も打り，勤労者のみでは ない。今回我々は，農業を主体とする世帯の多い

東海大学医学部耳鼻呐喉科学教室
自治体と, 市街地に近くサラリーマンの多い自治 体に同様のアンケート調査を実施し, 従来の勤労 者集団, メニエール病患者集団と比較したので報 告する。

\section{対 象}

勤労者集団 : 神奈川県内の一企業の全従業員に対 し，定期健康診断の際にアンケート調查に協力し てもらった。有効な回答が得られた 3 , 410名を対 象とした。男性が2,373名, 女性が1, 037名, 年柃 は19歳〜73歳, 平均41.3歳であった。 
農村地域 : 神奈川県内の協力を得られた一自治体 を対象とした。この自治体は農業を営む世帯が半 数以上を占める。20歳以上の任民を対象とし，ア ンィート調査表を配布した。郵送で回収し，有効 な回答の得られた155名を対象とした。男性が71 名, 女性が 84 名，年齢は20歳 88歳，平均 48.0 歳 であった。

市街地域 : 神奈川県内の協力を得られた一自治体 を対象とした。この自治体はサラリーマンを中心 とした核家族が多く，市街地に近い環境にある。 20歳以上の住民を対象とし，アンケート調查表を
配布した。郵送で回収し，有効な回答の得られた 639名を対象とした。男性が287名，女性が352名， 年龄は20歳〜86歳，平均 46.5 歳であった。 メニエール病患者：複数施設を受診したメニエー 儿病患者102名を対象とした。男性が29名，女性 が73名, 年齢は19歳〜 72歳, 平均 48.7 歳であった。 メニエール病の診断はメニエール病診断の手引き （厚生省研究班1974年）に基づき診断した。アン ケート調査は初診から 3 カ月以内に試行された。

\section{方 法}

従来使用したライフスタイルに関するアンチー

表 1 行動特性アンケート表

性格や行動についておたずねします。該当するものに○印をつけてください。

$$
\text { 0:そうではない } 1 \text { : まあまあそうである } 2 \text { : 大いにそうである }
$$

1 気性が激しい

$\begin{array}{lll}0 & 1 & 2\end{array}$

2 勝気である

3 仕事その他で、他人と競争する気持らを持ちやすい 0112

4 イライラしたり怒りやすい

$\begin{array}{lll}0 & 1 & 2\end{array}$

5 自分の意見を通そうとする

$\begin{array}{lll}0 & 1 & 2\end{array}$

つい人を批判してしまう

O 12

7 徹底的にやらないと気がすまない

$\begin{array}{lll}0 & 1 & 2\end{array}$

仕事その他に熱中しやすい

$\begin{array}{lll}0 & 1 & 2\end{array}$

9 熱中すると周囲が見えなくなる

O 12

10 話したくなると、一気に話さずにはいられない

0 112

11 毎日の生活の中で、時間に追われる感じがする

12 歩くのや食べるのが速い

13 休んで何もしないと、気持ちが落ち着かない

14 一度に二つのことをしようとする

15 周囲の目が気になる

16 人前で緊張しやす寸い

17 人の意見に合わせるほうである

18 親や上司の期待に沿うよう努める

O 12

19 嫌なことがあっても我慢する

$\begin{array}{lll}0 & 1 & 2\end{array}$

20 辛いことがあると、避けようとする

O 112

21 問題が生じると、他人のせいにしがちである

22 機嫌が悪いと、ついを責めてしまう

$\begin{array}{lll}0 & 1 & 2\end{array}$

23 取り掛かる前に、いろいろ心配する方である 
卜用紙を用い,アンケート調査を行った。これは 生活習慣，行動特性，ストレス源，気分転換の多 宾，自律神経失調的な症状よりなる。そのうち行 動特性を比較した（表 1 )。行動特性の調査項目 は, タイプ A 行動特性のうち, 攻撃因子 6 項目, 熱中因子 4 項目，時間切迫因子 4 項目，日本人に 多いといわれる自己抑制 5 項目，逃避 5 項目の計 24項目である。各項目について，そうではない， まあまあそうである，大いにそうであるの三つの 程度から選択してもらい，各程度の占める割合を 集団間で比較した。検定は $\chi^{2}$ 検定を用いた。

\section{結果}

行動特性24項目のらち，勤労者，農村地域，市 街地域の間で有意差 $(p<0.01)$ を認めた項目は なかった。メニエール病患者群と他の 3 集団の間 で著しい差 $(p<0.005)$ 認め大項目は，徹底的
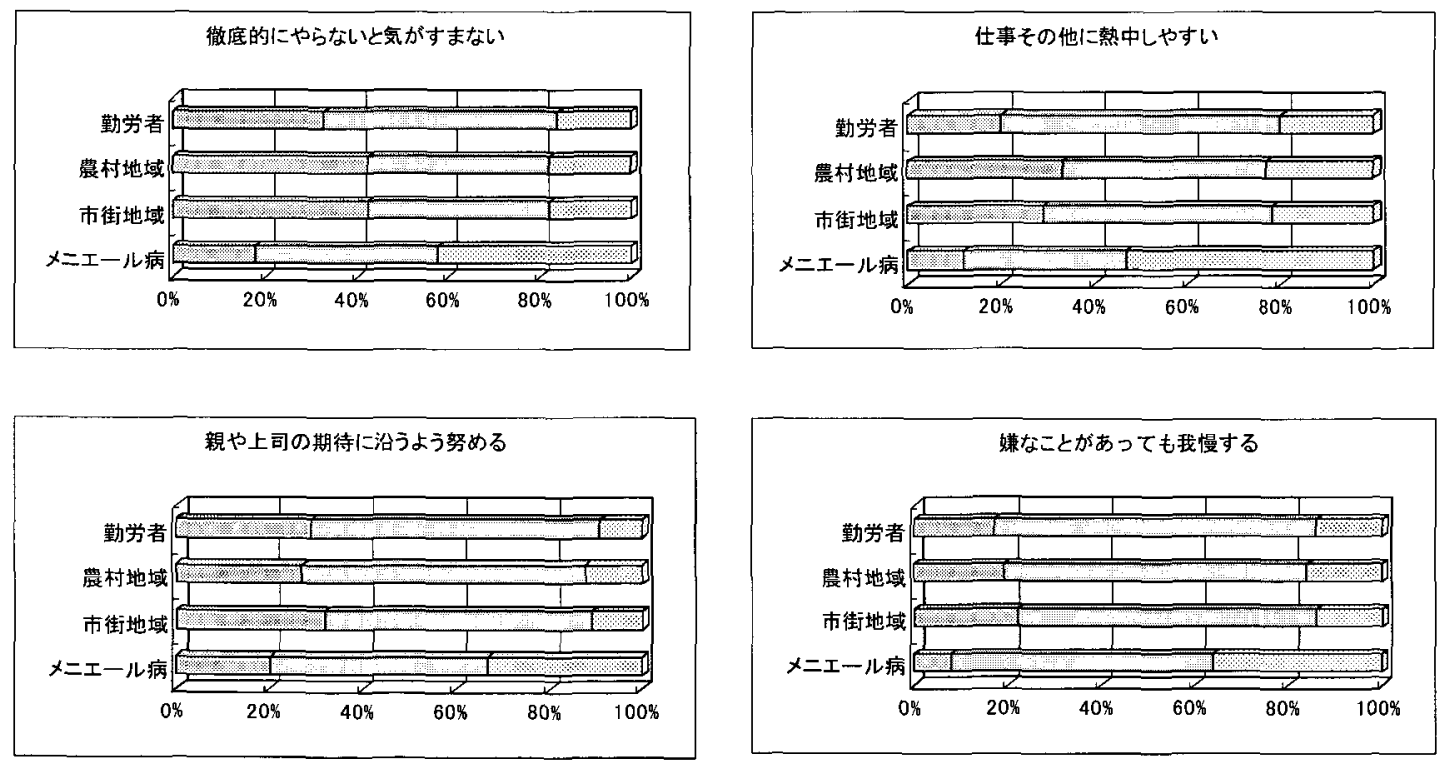

にやらないと気がすをない(熱中因子)，仕事そ の他に熱中しやすい（熱中因子），親や上司の期 待に沿うよう努める(自己抑制)，嫌なことが あっても我慢する (自己抑制)，取り掛かる前に いろいろ心配する方である(逃避）の 5 項目で あった（図 1)。休んで何もしないと気持ちが落 ち着かない（時間切迫因子）はメニエール病患者 群と勤労者, 市街地域で有意差 $(p<0.005)$ を認 め，一度に二つのことをしょうとする（時間切迫 因子）はメ二エール病患者群と勤労者，農村地域 で有意差 $(p<0.005)$ を認めた。イライラしたり 怒りやすい（攻撃因子）はメニエール病患者群と 勤労者の間で有意差 $(p<0.005)$ を認めた（表 2)。

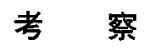

メニエール病の原因はいまだ解明されていない

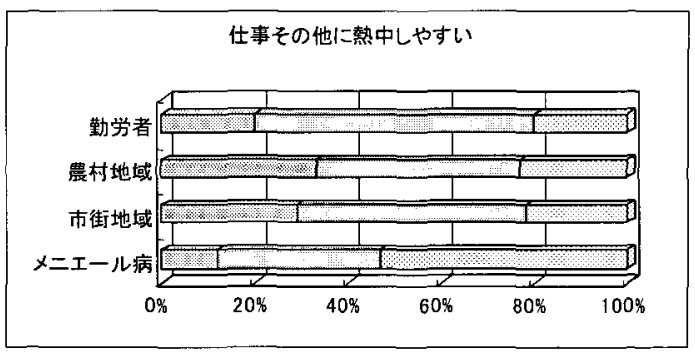

圆そうでない

まあまあそうである

大いにそうである 
表 2 複数の異なる一般集団とメニエール病患者群の行動特性の比較

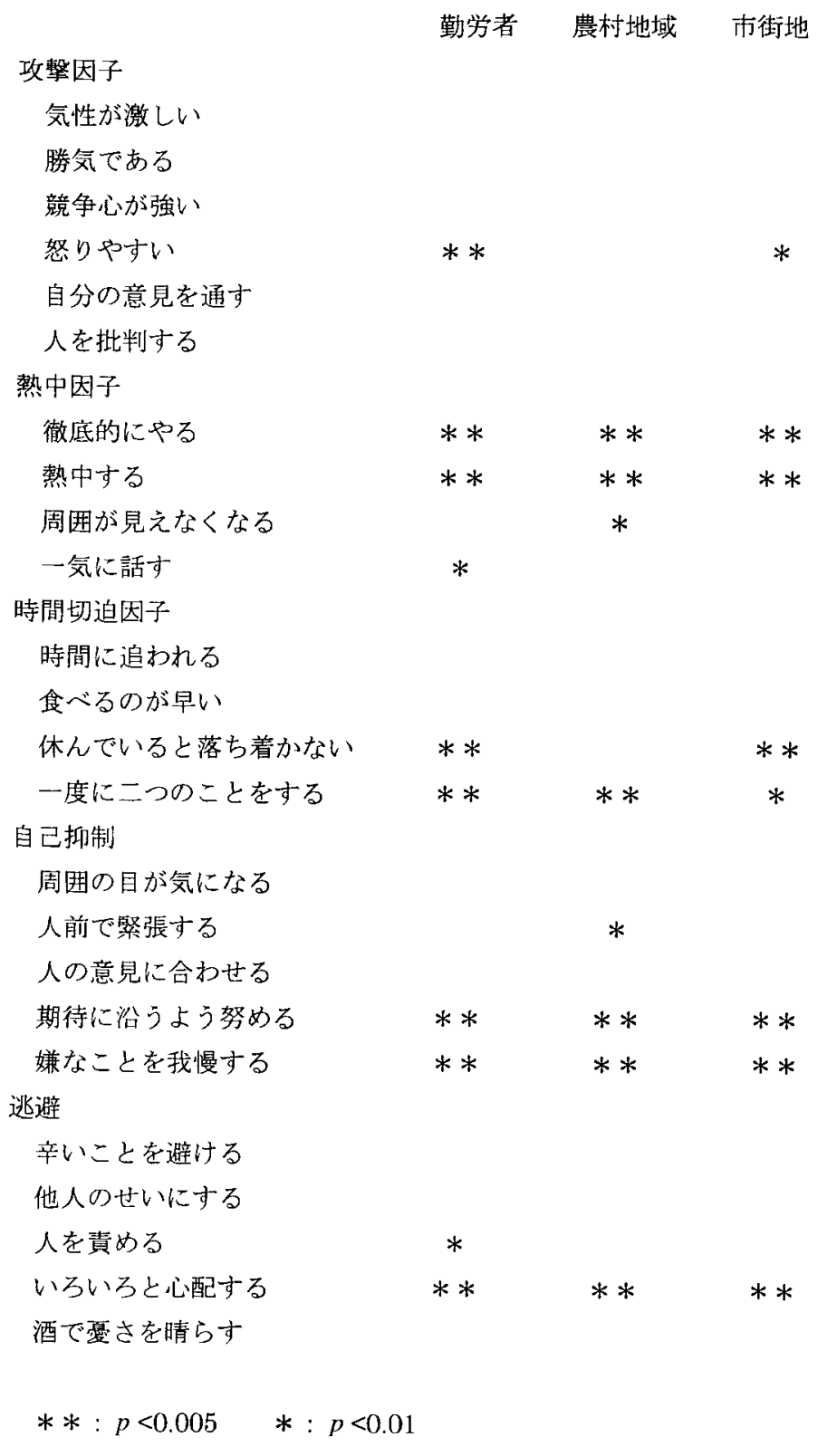

が,ストレスとの関係を示唆する報告は多(3) -5)。 ストレスはストレス源に対してとる対処行動に よって生じ，対処行動は各人の行動特性に大きく 左右される ${ }^{677)}$ 。行動特性を知ることは，その人 がストレスを受けやすい人か否かを判別する目安 となる。すべての人は様々なストレス源を持って いるが，多くの人はこれに対し何らかの解決方法
を持っており適切に対処する。しかし，ある種の 行動特性を有する場合, これらにらまく対応でき ず，ストレス反応を生じる。タイプ A 行動特性 と虚血性心疾患の関係到は有名であるが，メ二 エール病もこのよらな概念の疾患に当てはまる。 我々は勤労者集団との比較でメニエール病患者に 特異な行動特性が多くみられることを報告してき 
た。しかし、メニエール病患者は勤労者とは限ら ないため, 対象集団で生活環境の異なる可能性の あることを指摘された。今回，生活環境が行動特 性に及ぼす影響を知るために，勤労者集団と農村 地域，市街地域の間で調査比較したが，行動特性 に差はみられなかった。他の企業集団に詨し同様 のアンケート調查を行った過去の報告では各年代 で同じ傾向を示し，性差もなかった ${ }^{910) 。 こ の こ ~}$ 之か:ら，行動特性は生活環境や年㱓，性別の影響 が少ないと考えられる。どの環境, 年代, 性別で も，一定の割合で同じょらな特異な行動特性を持 つ人物が存在すると考光られる。これらの人はス トレス源に上手に対処できないため，自律神経失 調的な身体症状を生じる。メニエール病の発症, 增悪にも行動特性の関与が強く示咬された。発症 した患者はこのような行動特性の偏りの大きい集 団の一部と考えられる。

メニエール病患者の特異な行動特性として, 他 人の目を気にし，期待に沿うように努める，事前 に必要以上に心配しやすく，物事に熱中し，とこ とんやらないと気がすまないといらような人物像 が浮かび上がる。親や上司の期待に沿うよう努力 するが，期待ど和りの評価が得られないと報酬不 足がストレス反応となる。日本人のタイプ A 行 動特性は米国人のそれと比べ受動的である。タイ プ A 行動特性の熱中因子と, 自己抑制, いわゆ るイイ子行動特性が強くみられる。米国人の夕イ プ $\mathrm{A}$ 行動特性は独立した自由な個人として，自 己主張し, 他と敵対し, 競争し, 攻揧し, 社会的 に成功することに懸命になる。つまり，個人の成 功を得るために能動的である。一方日本人は，む しろ“つきあい”での急ぎ病であり，熱中的に， 徹底的に，多くを求めて仕事中毒になり，他から の誘いを断れず，約束したことは破らないという 強い義務感を持っている6)。我々のアンケート調

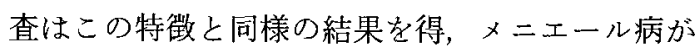
ストレスに関与して発症する疾患であることを裏 付けている。ながらくストレスが云々されてきた メニエール病であるが，ストレスの本体は不明で あった。今回の調查から, メニエール病の発症要 因として，行動特性が一段と重文る増したことに なる。

これらのことから当院では生活指導を行ってい る。生活指導によりストレス源に対する対処行動
の改善やストレス発散を目指している。これら治 療成績の蓄積が今後の課題であるが,メニエール 病を治癒するために有用な方法のひとつと考兄て いる。

\section{まとめ}

1.メニエール病患者の対象群として勤学者, 農村地域，市街地域を選び，ライフスタイルに関 するアンケート調查を行い，患者群と比較した。

2. 対象群である勤労者, 農村地域, 市街地域 間では，行動特性に差はみられなかったが，メ二 エール病患者群のみに特異な行動特性がみられ た。行動特性は生活環境に影響されないことが判 明した。

3.メニエール病を発症させたり増悪させるス トレスは，行動特性の雪で生ま狆ることが強く示 唆され，生活指導によるライフスタイルの改善が 必要と結論された。

\section{文献}

1) 大貫純一，高橋正紘，山下裕司: 勤労者 3,400 名における行動特性, ストレス源, ならびに 身体症状のアンケート調査結果. 前庭機能異 常に関する調查研究班平成12年度研究報告 書 : 57-60, 2001

2) 高橋正紘, 大貫純一, 小田桐恭子, 他: 一般 勤労者と内リンパ水腫患者のライフスタイ ル・アンケートの比較. 前庭機能異常に関す る調查研究班平成13年度研究報告書 : 73-76, 2002

3）水越鉄理, 猪 初男, 石川和光, 他: 厚生省 特定疾患 エール病の疫学調查と症状調查. 耳鼻臨床 70: 1669-1686, 1977

4) 渡辺 勈, 水越鉄理, 大久保仁, 他 : 前庭機 能異常に関する疫学調査報告一個人調查集計 を中心に一。耳鼻臨床 76:2420-2457, 1983

5 ) 渡辺行雄, 水越鉄理, 中川 綮, 他: メニエー ル病の症例対照調査結果一メニエール病確実 例と対照例：めまい症例, 一般症例, 健常者 との比較を中心に一- Equilibrium Res Suppl 7: 1-10, 1991

6) 宗像恒次：健康と病気の社会, 心理, 文化背 景. 最新行動科学からみ大健康と病気. 1-54 頁, メギカルフレンド社, 東京, 1996

7 ) 宗像恒次：ストレスと対処行動. 医療・健康 
心理学. 中川米造，宗像恒次編. 1-21頁，福 村出版, 東京, 1989

8) Friedman M, Rosenman RH: Association of specific overt behavior pattern with blood and cardiovascular findings; blood cholesterol level, blood clotting time, incidence of arcus senilis, and clinical coronary artery disease. J Am Med Assoc 169: 1286-1296, 1959

9) 山下裕司, 菅原一真, 下郡博明, 他: メニエ一 儿病患者の行動特性についてーアンケートに
よるストレスの定量化一. Equilibrium Res 57: 428-434, 1998

10）石田克紀, 飯田政弘, 高橋正紘, 他: メ二エ儿病と行動特性. 耳鼻臨床 94: 11-15, 2001

原稿到着: 平成 16 年 2 月 4 日

別刷請求先 : 大貫純一

下259-1193 神奈川県伊勢原市望星台

東海大学医学部耳鼻咽喉科学教室

E-mail: 0amcd001@is.icc.u-tokai.ac.jp 